Section Editor

Mitchell S.V. Elkind, MD, MS

\title{
Teaching NeuroImages: \\ "Pancake-like" gadolinium enhancement suggests compressive myelopathy due to spondylosis
}

Eoin P. Flanagan, MB.BCh

Richard W. Marsh, MD Brian G. Weinshenker, MD

Figure MRI cervical spine (sagittal T2 [A1, B1, and C1] and T1 post gadolinium [A2, B2, and C2])
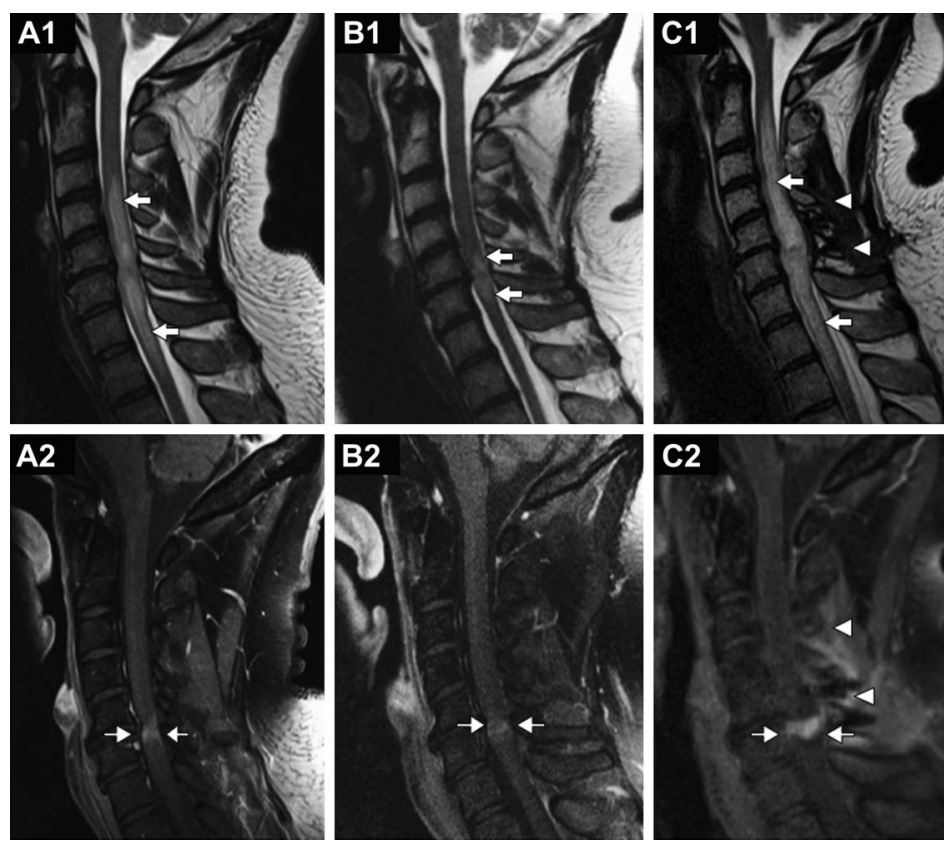

Hyperintense T2 signal 12 months (A1) and 2 months (B1) prior to surgery (thick white arrows) accompanied by flat "pancake-like" enhancement at the site of maximal stenosis (A2 and B2, thin white arrows). Changes persist/worsen (C1 and C2) 6 months after decompression surgery (white arrowheads) despite clinical improvement.

A 41-year-old man developed progressive bilateral hand weakness and spastic paraparesis. MRI demonstrated cord edema and "pancake-like" gadolinium enhancement (figure). Inflammatory/neoplastic causes were investigated and not found. He continued to deteriorate despite empiric corticosteroid treatment. One year later, cervical decompression stabilized his clinical condition but intramedullary T2 signal worsened. Persistent enhancement raised concern about alternative diagnoses.

"Pancake-like" enhancement due to focal disruption of the blood-brain barrier at the point of maximal stenosis ${ }^{1}$ strongly suggests cervical stenosis ${ }^{2}$ as the cause of the myelopathy. Enhancement may persist after successful surgery. ${ }^{1}$ Inflammatory/neoplastic myelopathies have long rostrocaudal segments of enhancement. ${ }^{2}$ Recognition of this radiologic feature may prevent subsequent disability.

\section{AUTHOR CONTRIBUTIONS}

Dr. Flanagan was involved in drafting and revising the manuscript for content, including medical writing for content, analysis and interpretation of data, and acquisition of data. Dr. Marsh was involved in revising the manuscript for content and analysis and interpretation of data. Dr. Weinshenker was involved in drafting and revising the manuscript for content, including medical writing for content, analysis and interpretation of data, acquisition of data, and study supervision.

\section{STUDY FUNDING}

No targeted funding reported.

\section{DISCLOSURE}

The authors report no disclosures relevant to the manuscript. Go to Neurology.org for full disclosures.

\section{REFERENCES}

1. Sasamori T, Hida K, Yano S, Takeshi A, Iwasaki Y. Spinal cord swelling with abnormal gadolinium-enhancement mimicking intramedullary tumors in cervical spondylosis patients: three case reports and review of the literature. Asian J Neurosurg 2010;5:1-9.

2. Kelley BJ, Erickson BJ, Weinshenker BG. Compressive myelopathy mimicking transverse myelitis. Neurologist 2010;16: $120-122$.

From the Departments of Neurology (E.P.F., B.G.W.) and Neurosurgery (R.W.M.), Mayo Clinic, Rochester, MN. 


\section{Neurology}

\section{Teaching NeuroImages: "Pancake-like" gadolinium enhancement suggests compressive myelopathy due to spondylosis}

Eoin P. Flanagan, Richard W. Marsh and Brian G. Weinshenker

Neurology 2013;80;e229

DOI 10.1212/WNL.0b013e318293e346

\section{This information is current as of May 20, 2013}

\section{Updated Information \& Services}

References

Citations

Subspecialty Collections

Permissions \& Licensing

Reprints including high resolution figures, can be found at: http://n.neurology.org/content/80/21/e229.full

This article cites 2 articles, 0 of which you can access for free at: http://n.neurology.org/content/80/21/e229.full\#ref-list-1

This article has been cited by 3 HighWire-hosted articles: http://n.neurology.org/content/80/21/e229. full\#\#otherarticles

This article, along with others on similar topics, appears in the following collection(s):

\section{All Spinal Cord}

http://n.neurology.org/cgi/collection/all_spinal_cord

Disc disease

http://n.neurology.org/cgi/collection/disc_disease

\section{MRI}

http://n.neurology.org/cgi/collection/mri

Information about reproducing this article in parts (figures,tables) or in its entirety can be found online at:

http://www.neurology.org/about/about_the_journal\#permissions

Information about ordering reprints can be found online: http://n.neurology.org/subscribers/advertise

Neurology ${ }^{\circledR}$ is the official journal of the American Academy of Neurology. Published continuously since 1951, it is now a weekly with 48 issues per year. Copyright @ 2013 American Academy of Neurology. All rights reserved. Print ISSN: 0028-3878. Online ISSN: 1526-632X.

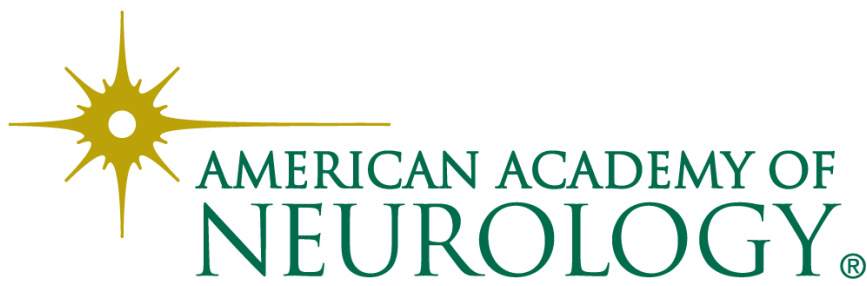

